\title{
Hodgkin's Lymphoma in a Developing Community
}

\author{
Wilson IBOnuigbo* \\ Medical Foundation and Clinic, Nigeria
}

Received: 制 June 26, 2018; Published: 畊July 09, 2018

*Corresponding author: Wilson IBOnuigbo, Medical Foundation and Clinic, 8 Nsukka Lane, Enugu 400001, Nigeria

\begin{abstract}
As a scholar, who published a biographical paper on Thomas Hodgkin, it seemed appropriate to undertake research on the disease that bears his name. In sum, following the known importance of the histopathology data pool in epidemiological analysis, this study is based on such a pool established among the Igbos, a major ethnic group in Nigeria.
\end{abstract}

Keywords: Thomas Hodgkin; History; Lymphoma; Histopathology; Igbos; Nigeria; Ethnic Group; Epidemiological; Hodgkin’s Disease; Mini-Library

\section{Introduction}

As a medical student at Glasgow University, I had the privilege of "Open Access to the Shelves," thereby being able to handle the original works of Thomas Hodgkin [1]. In due time, I published his detailed biography [2]. Therefore, following on the theme that a histopathology data pool facilitates epidemiological analysis [3], I made use of such a pool serving the Igbo ethnic group in their developing community[4]. This should facilitate knowledge of the local epidemiological aspects of this classical disease.

\section{Investigation}

I encouraged Doctors working in this community to send to me the biopsy specimens provided that they were appropriately fixed with formalin and accompanied by details concerning age, sex, and other useful data. As my practice was to keep a personal copy, their manual sorting became useful. Therefore, the present work on cases of Hodgkin's disease became possible.

\section{Results}

Of the 90 total cases, the male/female ratio was approximately $3 / 1$. The ages ranged from 5 years to 76 years. The second decade suffered most. Other epidemiological data included the towns of origin. In sum, whereas the Capital City, Enugu, took the pride of place in 56 (62.2\%) cases, the rest came from towns as far apart as Aba, Abakiliki, Adazi, Afikpo, Aku, Enugukwu, Ihiala, Ogwashiukwu, Onitsha, Orumba, Udi, Ukpo, and Umuahia.With regard to the biopsy sites, the neck preponderated in 38 (42.2\%) cases. This was followed by 2 or more sites in 30 (33.3\%) cases. The remainders came from the groin, axilla and even from inside the abdomen(Table 1).
Table 1:Age, sex and data.

\begin{tabular}{|c|c|c|c|}
\hline Age & M & F & Total \\
\hline$<10$ & 8 & 1 & 9 \\
\hline $11-20$ & 18 & 10 & 28 \\
\hline $21-30$ & 13 & 5 & 18 \\
\hline $31-40$ & 5 & 0 & 5 \\
\hline $40-50$ & 10 & 5 & 15 \\
\hline $51-60$ & 5 & 5 & 10 \\
\hline $61-70$ & 2 & 1 & 3 \\
\hline $71+$ & 2 & 0 & 2 \\
\hline Total & 63 & 27 & 90 \\
\hline
\end{tabular}

\section{Discussion}

According to the Editor of English for Specific Purposes[5], I was by 1986 probably the highest researcher in the Reprint Request (RR) traffic! In this context, on searching my mini-library of reprints, there were in the 1980s reports from South Africa [6], Puerto Riso[7], Jamaica [8], Jordan [9], India [10-12], Greece [13], and Uganda [14]. Therefore, how do their findings compare with the local data? In general, the disease preponderates in males and younger elements. Moreover, palpable neck nodes were useful guides for the diagnostic biopsy, which may involve the opening of the abdomen for the diagnosis.

\section{References}

1. Hodgkin T (1843) On the anatomical characters of some adventitious structures, being an attempt to point out the relation between the microscopic characters and those which are discernible by the naked eye. Med Chir Trans 26: 242-428. 
2. Onuigbo WIB (1964) Thomas Hodgkin (1798-1866) on cancewr cell carriage. Med Hist 11: 406-411.

3. Macartney JC, Rollaston TP, Codling BW (1980) Use of a histopathology data pool for epidemiological analysis. J Clin Pathol 33(4): 351-355.

4. Basden GT. Niger Ibos. Cass, London (1966).

5. Swales J. ESP in the big world of reprint requests. Eng Specific Purposes, 1986; 5(1): 81-85.

6. Cohen C, Hamilton DG (1980) Epidemiologic and histologic patterns of Hodgkin's disease comparison of the black and white populations of Johannesburg, South Africa. Cancer 46(1): 186-189.

7. Nunez LR, Velez Garcia E, Velazquez J, Delgado E (1982) Hodgkin's disease: A histopathologic review of cases seen at the University hospital (San Juan, Puerto Rico), 1969-1978. Puerto Rico Hlth Sci J 1(3): 131-134.

8. Hanchard B, Lofters WS, Gibbs WN, Cambell M, Morgan O (1982) Hodgkin's disease in Jamaica changing patterns in histological subtypes. W I Med J 31(2): 61-63.

\section{ISSN: 2574-1241}

DOI: $10.26717 / B J S T R .2018 .06 .001364$

Wilson IBOnuigbo. Biomed J Sci \& Tech Res

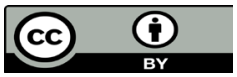

This work is licensed under Creative Commons Attribution 4.0 License

Submission Link: https://biomedres.us/submit-manuscript.php
9. Tarawneh MS, Madanat F, Khalaf MA, Awidi AS, Amr SS et al. (1984) Hodgkin's disease in Jordanian children: a study of 26 cases. Clin Oncol 10(1): 21-25.

10. Dinshow K, Pande S, Advani S, C Nair, DN Rao, et al. (1985) Pediatric Hodgkin's disease in India. J Clin Oncol 3(12): 1605-1612.

11. Talvalkar GV, Gangadharan P (1982) Hodgkin's disease in Western India Review of 1082 cases. Cancer 50(2): 353-359.

12. Shanta V, Sastri DVLN, Sagar TG, Sasikala K, Krishna Murthi S (1982) A review of Hodgkin's disease at the Cancer Institute, Madras. Clin Oncol 8(1): 5-15.

13. Floros D, Papakyriazis N, Boutis L, Symeonidis A (1982) Hodgkin's disease in Greece: A retrospective clinic pathologic study of 78 cases. J Surg Oncol 20(2): 119-123.

14. Olweny CLM, Katongole Mbidde E, Kiire C, Lwanga SK, Magartha I et al. (1978) Childhood Hodgkin's disease in Uganda. Cancer 42(2): 787-792.

$\begin{array}{ll}\text { BIOMEDICAL } & \text { Assets of Publishing with us } \\ \text { RESEARCHES } & \text { Global archiving of articles } \\ & \text { - Immediate, unrestricted online access } \\ & \text { - Rigorous Peer Review Process } \\ & \text { - Authors Retain Copyrights } \\ & \end{array}$

